\title{
Study of soil erosion risks using remote sensing in Ouergha River watershed (Morocco)
}

\author{
Imane JAOUDA, Ahmed AKHSSAS, Latifa OUADIF, Lahcen BAHI, Jada ELKASRI, Hanane SOUIDI and \\ Halima SOUSSI.
}

Mohammadia Engineering School, Mohammed V University in Rabat, Morocco

\begin{abstract}
The watershed Ouergha River located in the north of Morocco suffer from vegetation cover degradation, this geographic entity is experiencing intense water erosion linked to the combination of several natural factors, such as the roughness and abundance of rainfall and the predominance of soft geological formations. Human intervention in this vulnerable environment accentuates its fragility by the clearing and degradation of the vegetation cover and the cultivation of land with a steep slope.

This work aims to map the spatiotemporal evolution of this degradation by using the spot and Landsat images and the Radar image over a period from 1990 to 2014 data and aims to model its processes of erosion.

In fact, the analysis of satellite data identified six main types of land use (eau, foret, reboisement...). It has also shown that the most degraded soils aren't necessarily those with the greatest erosion rates over the past 15 years and that some soils that have developed well over time have become major exporters of sediments after clearing and cultivation.

The comparison of the results of land use has highlighted the harmful impact of human practices on the acceleration of soil degradation.

Human intervention, coupled to frequent and severe drought periods, remain the most important factors in the weakening and increasing vulnerability of soils to degradation.

The results obtained by this approach made it possible to identify and monitor vulnerable areas at Ouergha watershed where interventions are needed to limit the processes of degradation of the soil and the natural environment.

Keywords: Erosions, Ouergha watershed, Degradation, forest, Landsat images, SIG, Morocco.
\end{abstract}

\section{Introduction}

Soil erosion characterizes the majority of Morocco's reliefs and a spectacular expansion of erosion processes reveals some of the most disturbing aspects. As a result, soil degradation upstream of the basins is the cause of the siltation of dams and the decreasing storage capacity of Morocco's dams with a 75 million m3/year (HCEFLCD 2013) [1]. Moreover, the human context is difficult and generally characterized by a high density of the rural population.

The risk of erosion imposes significant costs on agriculture by reducing soil productivity and also contributes to forest degradation.

The first results showed the importance of erosion in the Ouergha river watershed and revealed that the combined erosion forms are significant (leaf, gullies and gullies) and numerous factors, both physical and human, promote the risk of erosion (HCP 2014)[2].

The objective of this paper is to map the erosion factors and to develop a dynamic methodology to identify and visualize development scenarios and to compare the degradation of the vegetation cover between 1990 and 2014 .

\section{Materials and methods}

The main objective of this study is to improve knowledge of hydro-geomorphological processes in order to help decision-makers on good environmental governance and better long-term cohabitation with the effects of soil erosion. Preparation of input data and spatial analysis of 
erosion risks in the Ouergha River basin are produced in the GIS environment tool (The RUSLE model not only estimates the average annual soil loss for existing conditions, but also allows to simulate how a change in land use, climate change, and/or change in conservation / Management, will affect the vegetation cover). Therefore, simulation of biophysical and hydro-meteorological data is based on empirical models to analyze and produce decision maps that are useful for the prevention of soil loss at the Al Wahda dam.

\subsection{Study Area}

The watershed of the El WAHDA dam is drained by Ouergha river. It covers an area of $6190 \mathrm{~km} 2$. It is located in the north of Morocco between latitudes $34^{\circ} 25^{\prime}$ and $35^{\circ} 25^{\prime}$, and longitudes $-5^{\circ} 24$ 'and -3 ${ }^{\circ} 45$ ', it extends over most of the Rifain mountain. It is bounded on the north by the Rifan peak passing through the rural commune Ketama, Bab Berred and Bab Taza, distant from the Mediterranean by about $30 \mathrm{~km}$, in the South, by the watersheds of the prerifain tributaries of the Sebou river and in the east by the tributaries of the Moulouya river and Sebou of eastern prérif region. (Fig. 1).

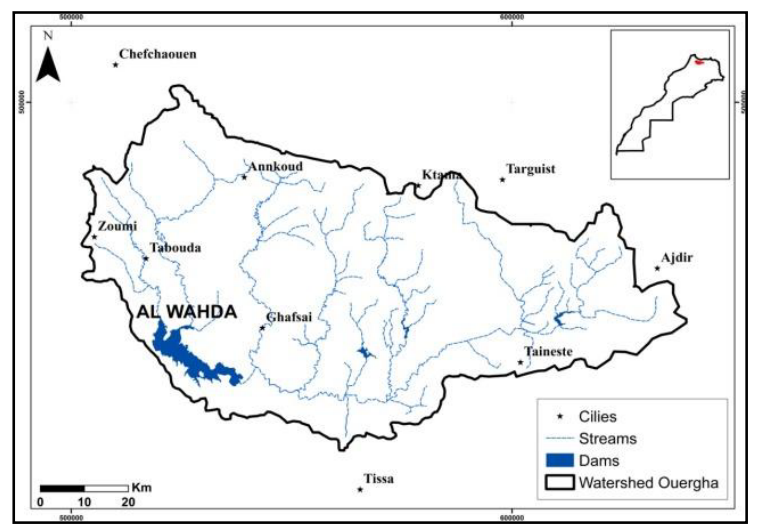

Figure 1: Geographic location of the Oued Ouergha watershed.

The substratum of the basin is formed essentially by clays and cretaceous marls preventing the infiltration of rainwater. The Ouergha basin has an index of 1.6; with three major topographical areas: high altitude $(>1500 \mathrm{~m})$; average altitude (from 500 to $1500 \mathrm{~m}$ ) and hills and plains of the valleys $(<500 \mathrm{~m})$ (fig. 2$)$.

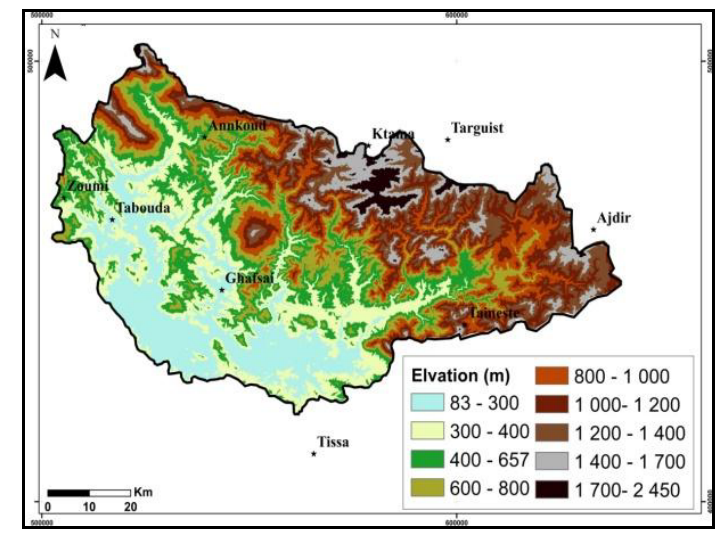

Figure 2: Hypsometric map of Ouergha River Basin.

Geologically, the watershed of Oued Ouergha is shaped in a part of each of the two structural assemblages (the Intra-Rif, the Meso-Rif) separated by the Tahar Souk basin which is a basin with post plies tortoises deposits. Post-plie deposits are indigenous Miocene formations deposited during the Tortonian transgression. They consist of conglomerate coarse sediments at the base and become finer upwards giving sandstones, ending in a thick series of clayey marls. The northern part of the watershed is the intra-Rifi zone, formed by two thrust sheets; the units of Ketama and Tangier (Asebriy et al., 2003; 2006;2007).[3-5]

The hydrographic network of the Ouergha watershed runs for a length of about $1486 \mathrm{~km}$, the main tributaries of the Ouergha are the Sra, Amazaz, Aoulay and Aoudour wadis (fig.3). The basin contains four dams from upstream: Asfalou, Bouhouda, Sahla and Al Wahda.

The mapping of the Watershed in the Geographic Information System (GIS) provides a total area of $6190 \mathrm{~km} 2$ with an elongated form. Concerning climate context, the Oued Ouergha watershed has characteristics of the Mediterranean climate with a rainy winter and a dry summer (ABHS 2012).[6] 


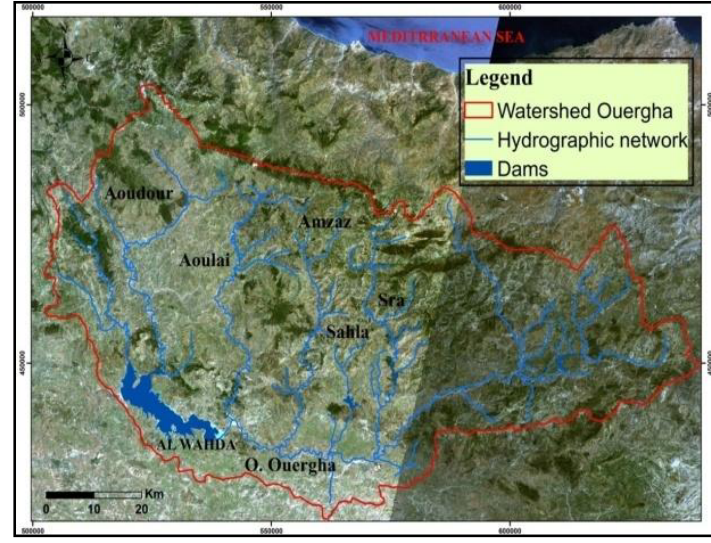

Figure 3: Hydrographic of the Ouergha River $\underset{\text { vv aumsucd }}{\text { A }}$

\subsection{Materials and methods}

Our approach is based on the use of remote sensing data for a spatialized knowledge of the differentiation factors of erosion and on the use of the geographic information system. For multi-date monitoring of erosion at the watershed scale, four satellite images were used: a Spot HRV prize image on November 15, 1990 and three Landsat images taken: February 09, 1990 (thematic Mapper TM sensor, 25 April 2014 and October 24, 2014 (Enhanced Thematic mapper ETM +). This procedure is illustrated in figure 4.

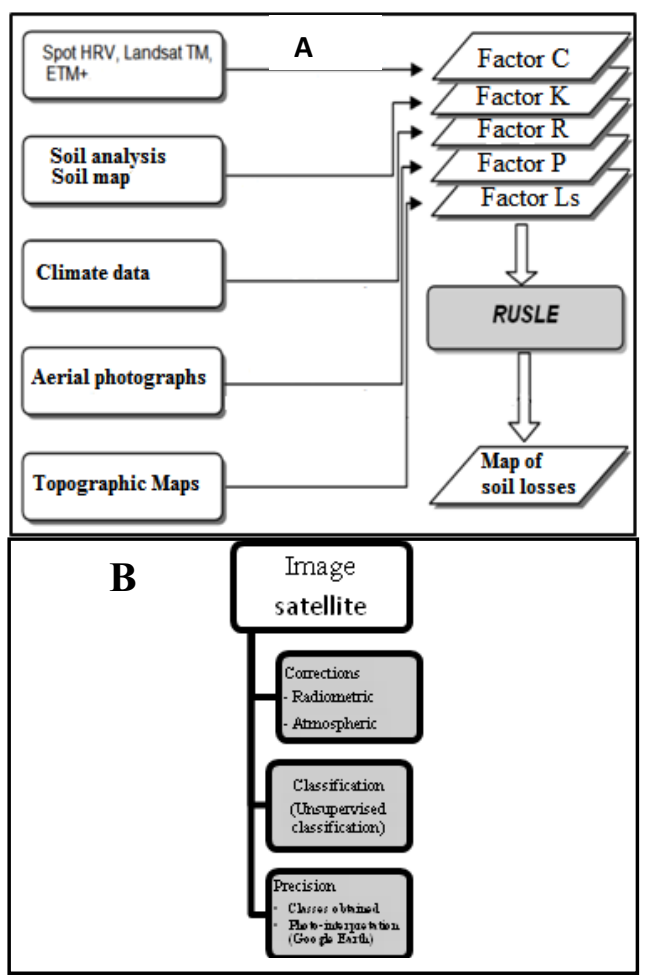

Figure 4: A: Schematic representation of the integration of the Universal Ground Loss Equation; B: Steps in the development of the map of the vegetation cover.

The input data and the spatial analysis of the risk of erosion in the Oued Ouergha sub-watersheds are produced in the GIS environment tool. therefore, the simulation of biophysical and hydrometeorological data is based on empirical models (Universal Soil Loss model, Gradex model and Francou-Rodier method) to analyze and produce decision maps useful for the prevention of soil loss and Al dam Wahda siltation. this vulnerability assessment is qualitative and does not include temporal variations. This is mainly due to insufficient data on vulnerability, in particular due to the lack of historical information on potential damage.

The data used for the susceptibility analysis are grouped into five groups of explanatory variables linked to climatic, topography (gradient/length slopes),, geological and geo-morphological data, hydrographic parameters (river density) and soil occupation. Thus, thematic maps are produced by geo-processing of obtained information.

The interpretation of the soil characteristics is used to classify soils in the Wischmeier Abacus and to approach erodibility factor (Roose 1991; 1977).[67]

Thus, the land cover map is extracted from SPOT satellite images (resolution of $20 \mathrm{~m}$ ) combined with recent Landsat ETM+ imagery through the supervised classification method.

The soil susceptibility is simulated by the Universal Soil Loss model (Wischmeier 1965; 1978) [8,9] considered as the most robust approach for spatial assessment of the soil erosion hazard.

$$
A=\text { R.K.LS.C.P }
$$



A: Average annual soil loss (ton/ha/year)
R: Rainfall erosivity factor.
K: Soil erodibility factor. slope gradient.
C: Land cover factor.
P: Erosion control practices factor.

LS: Topographical factor with slope length and

\section{Results and discussion}

The analysis of satellite data identified six main types of land use (badlands), cereal crops, mixtures of cereal crops and arboriculture, olive trees, reforestation and clear forest) in the Ouergha River Watershed (fig.6). The diachronic study of land use reveals a change in the natural environment with forest degradation $(+67 \%)$, an extension of heavily eroded soils (badlands and uncultivated land). This increase is linked to climate change, entropic activities, and a reduction of cereal-growing areas ($19 \%$ ) in favor of cultivation in the presence of arboriculture.

After the land-use mapping for each date of filming, soil losses were estimated by the RUSLE modules integrated into the GIS. (fig.5).

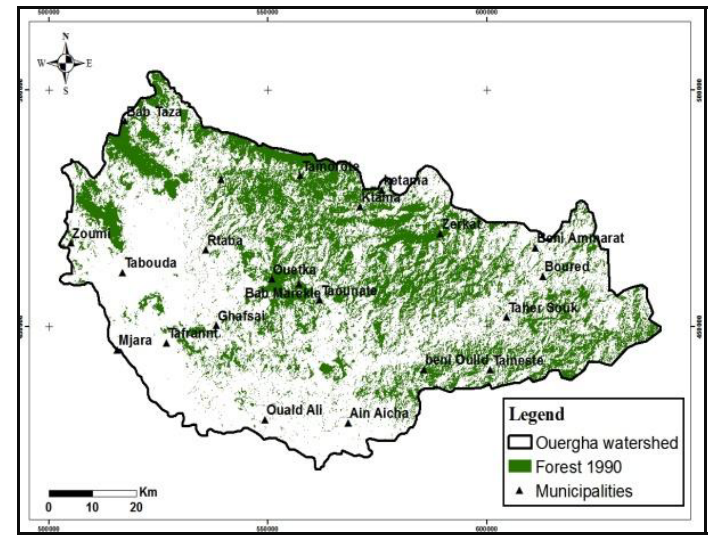

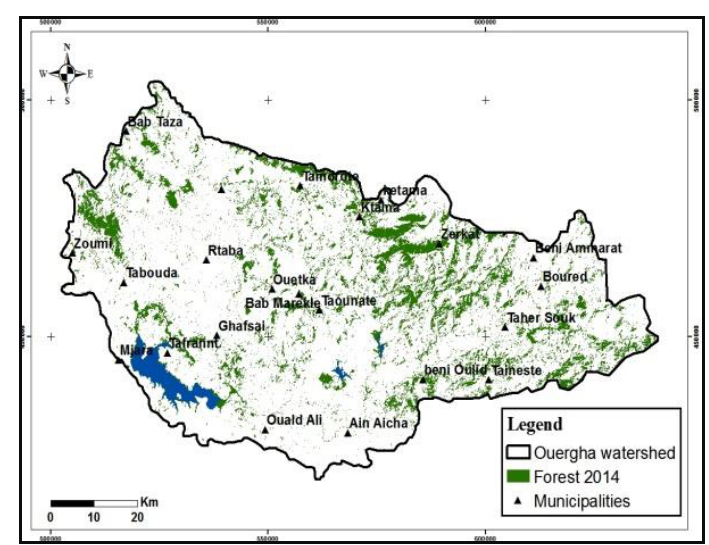

Figure 5: Evolution of forest degradation between 1990 and 2014 in the Ouergha watershed.

These maps show both the extent of land losses in the basin and their variability in space. The weighted mean losses determined by RUSLE by land-use types range from $61.14 \mathrm{t} / \mathrm{ha} / \mathrm{yr}$ as the minimum value measured in the matorrals (drill) and $300 \mathrm{t} / \mathrm{ha} / \mathrm{yr}$ as the maximum value recorded for badlands and uncultivated land (Fig.6). The latter generally correspond to regosols or unsophisticated erosion soils that are poorly protected and located on steep slopes. The land occupied by annual (arable) crops also shows a high susceptibility to erosion with annual losses of $84.68 \mathrm{t} / \mathrm{ha} /$ year.

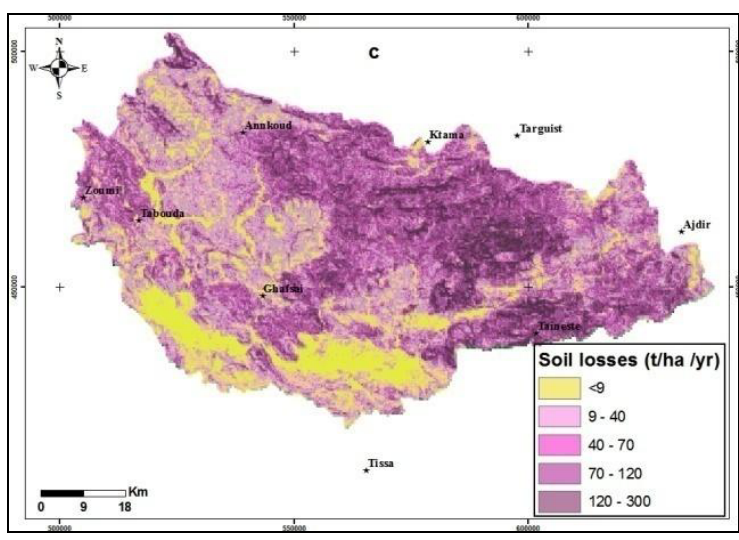

Figure 6: Maps of soil loss in Ouergha River watershed. The comparison of these results with previous studies (Al Karkouri 2003); (Dhman 1994); (El Garouani 2003); (Heusch 1970); (Rahhou 1999) [10-14] shows that the temporal variability of the erosion process has been taken into account in general leads to decrease the soil erosion value. On the basis of averages for certain types of land use, 
there is an increase in the risk of erosion over time in the mountainous regions of the eastern slope of the Ouergha watershed (Jaouda et al., 2018)[15].

\section{Conclusion}

The present study has shown a cartographic approach based on the integration of spatial remote sensing tools (GIS) and télédetection analysis functionalities linked to the initial state of Ouergha River watershed to study vulnerable areas to erosion and the process of degradation of this Basin.

Analysis of remote sensing data reveals a change in natural area with an extension of badlands and uncultivated land $(+67 \%)$, an increase in olive areas $(+53 \%)$, a reduction in areas of Cereal crops in favor of cultivation in the presence of arboriculture $(-19 \%)$ and areas occupied by matorral and reforestation haven't undergone any significant change.

The results of the calculations of annual soil losses in the Ouergha River Watershed show: A great brittleness in the eastern and southeastern part of the basin mainly marls and Miocene sandstone marls (up to 50t/ha/year), approximately 1250 ha, or $9.5 \%$ of the total area of the basin. Low erosion rates $(<9 \mathrm{t} / \mathrm{ha} / \mathrm{yr})$ predominantly occur on the slopes of the right bank of the basin where a matorral based on holm oaks and olive trees covers sandstones and areas with low losses in soil corresponding to areas of low slope or plains. The technique used enables the rapid assessment of net erosion at the basin scale and the identification of areas requiring interventions to control soil degradation. 


\section{REFERENCES}

1. HCEFLCD (Haut Commissariat aux Eaux et Forêts et à la Lutte Contre la Désertification) 2013. Plan d'Action du Haut Commissariat aux Eaux et Forêts et à la Lutte Contre la Désertification.

2. Asebriy L., Azdimousa A., Bourgois J., Poupeau G. \& Montigny R. 2003. Histoire thermique et surrection du Rif externe et des nappes de flyschs associées (Nord Maroc). Trav. Inst. Sci., Rabat, sér. Géologie \& Géogr. phys., 21, 15-26.

3. Asebriy L., Azdimous A., Poupeau G., Rezqi H., Bourgois \& Aït Brahim L. 2006. Géodynamique des bordures méridionales de la mer d'Alboran; application de la stratigraphie séquentielle dans le bassin néogène de Boudinar (Rif oriental, Maroc). Bulletin de l'Institut Scientifique, Rabat, section Sciences de la Terre, $\mathrm{n}^{\circ} 28,9-18$.

4. Asebriy L, Azdimousa1 A., Jabaloy A., BoothRea G., F. González-Lodeiro and J. Bourgois 2007. Lithostratigraphy and structure of the temsamane unit (eastern external rif, morocco). Revista de la Sociedad Geológica d'España, 20 (3-4).

5. ABHS (Agence du Bassin Hydraulique de Sebou) 2012. Etude d'actualisation du Plan Directeur d'Aménagement Intégré des Ressources en Eau du bassin de Sebou.

6. Roose E. 1977. Travaux et Doc. ORSTOM 78 (1977) 37-69 Paris: ORSTOM (3e trim).

7. Roose E. 1991. Cah. ORSTOM, sér. Pédol. 2, 145-181 Paris: ORSTOM.

8. Wischmeier W.H., Smith D.D. 1965. U.S. Department of Agriculture Handbook 282 Washington: US. Govt. Printing Office.

9. Wischmeier W.H., Smith D.D. 1978. U.S. Dept. Agriculture. Agric. Handbook 537-60 USA: US. Govt. Printing Office.

10. Al Karkouri J. 2003. Dégradation du milieu naturel dans le bassin de Beni Boufrah (Rif Central - Maroc) : analyse des facteurs et des processus, essai de quantification et modélisation spatiale. Thèse d'Etat, Univ. Mohamed V, Faculté des Lettres, p 392.

11. Dhman H. 1994. Utilisation des SIG et des télédétections dans l'étude de l'érosion hydrique: application au bassin versant de Tleta. Mémoire de troisième cycle, ENFI, Salé, p 120.

12. El Garouani A., Merzouk A., Jabrane R.,. Boussema M.R. 2003. Cartographie de l'érosion des sols dans le bassin versant de
l'Oued Jemâa (Pré-rif, Maroc). Géomaghreb, Vol. 1, n 1(), p. 39-46.

13. Heusch B. 1970. L'érosion dans le Pré-rif: une étude quantitative de l'érosion hydraulique dans les collines marneuses du Pré-rif occidental. Annales des recherches forestières, Vol. 12, Rabat, p. 9-176.

14. Rahhou M. 1999. L'érosion dans le Prérif central, zone interfluviale Leben-SebouOuergha, un prolongement de l'évolution naturel, une production sociale. Thèse d'Etat, Univ.Mohammed V, Rabat. 300 p.

15. JAOUDA I., AKHSSAS A., OUADIF L., BAHI L., LAHMILI A. (2018). Stabilité des talus et impact sur le réseau routier: cas du bassin versant d'Ouergha (Maroc). MATEC Web of Conferences 149, 02052 (2018) https://doi.org/10.1051/matecconf/2018149020 52 CMSS-2017. 